\title{
Daily Intake of Aflatoxins from Cocoa (Theobroma cacao) Product in Cote D'ivoire
}

\author{
Adama COULIBALY ${ }^{1}$, Komissiri DAGNOGO ${ }^{2}$, Daouda SIDIBE $^{3}$, Nahoulé SILUE ${ }^{4}$, Ardjouma \\ DEMBELE ${ }^{5}$, Godi Henri BIEGO ${ }^{6}$ \\ ${ }^{1}$ Central Laboratory of Agrochemistry and Ecotoxicology, Cote d'Ivoire \\ Laboratory of Biochemistry and Food Sciences, UFR Biosciences, Abidjan-Cocody University Houphouet Boigny, Cote d'Ivoire \\ ${ }^{2,5}$ Central Laboratory of Agrochemistry and Ecotoxicology, Cote d'Ivoire \\ ${ }^{3,6}$ Laboratory of Biochemistry and Food Sciences, UFR Biosciences, Abidjan-Cocody University Houphouet Boigny, Cote d'Ivoire \\ ${ }^{4}$ Institute of Agropastoral Management, University Peleforo Gon Coulibaly Korhogo, Côte d'Ivoire
}

\begin{abstract}
The objective of this study is to estimate the risk of exposure to aflatoxins cocoa bean (Theobroma cacao) produced in Côte d'Ivoire. Thus, 113 samples (66 samples collected during the 2011-2012 season and 47 during that of 2012-2013) were analyzed. Aflatoxin was extracted from the samples by the modified method of Le Tutour et al., (1983) and assayed by high performance liquid chromatography (HPLC) according to the standards of the European Communities (EC 401/2006). Aflatoxin intakes were estimated from daily consumption of cocoa beans from the adult Ivorian and levels of aflatoxins found in the cocoa mass. The mean concentrations of aflatoxin B1 (AFB1) and total aflatoxin (AFT) found in the cocoa mass were respectively $1.31 \pm 0.48 \mu \mathrm{g} / \mathrm{kg}$ and $2.36 \pm 0.61 \mu \mathrm{g} / \mathrm{kg}$. The AFB1 was found in $58 \%$ of samples with higher contents to normative values of the European Commission in $20 \%$ and $16 \%$ respectively for $\mathrm{AFB1}(2 \mu \mathrm{g} / \mathrm{kg})$ and AFT $(4 \mu \mathrm{g} / \mathrm{kg})$. The estimated intakes for AFB1, are $25.2 \mathrm{pg} / \mathrm{kg} \mathrm{body} \mathrm{weight/day} \mathrm{and}$ $266.5 \mathrm{pg} / \mathrm{kg}$ body weight/day, respectively for small and large Ivorian consumers. These calculated contributions represent 16.8\% and $177.7 \%$ of the Toxicity Reference Value (VTR) stable by European and international committees. According to the VTR, the levels of aflatoxins detected in the mass cocoa are not likely to cause toxicity to the small Ivorian consumer. However, health risks remain for regular Ivorian consumer because of the potential synergy of toxins and exposure over long periods at these doses determined.
\end{abstract}

Keywords: aflatoxins, cocoa mass, health risk, daily intake

\section{Introduction}

Aflatoxin B1, B2, G1 and G2 are mycotoxins produced by molds of the genus Aspergillus [1]. The fear caused by these aflatoxins is from the danger they pose to humans and animals. Indeed, the primary target organ for aflatoxins is the liver [2]. They can also disrupt the immune system, cause growth retardation and possibly death in humans and pets [3]-[6]. Aflatoxin B1 is also teratogenic, immunosuppressive and could affect reproductive functions [7]. It was also proved that aflatoxins significantly slow the recovery of child victims of protein-calorie malnutrition [8]. Furthermore, exposure to high amounts of aflatoxin, at weaning, can affect the growth of children as some authors have pointed to Benin and Togo [9], [10].

The presence of aflatoxins alters the health quality of contaminated food (nuts, corn, peanuts, oil seeds, spices, dried fruits, cocoa products) [11]. In 2004, aflatoxins have been responsible for the deaths of 80 people in Kenya following the consumption of corn flour heavily contaminated aflatoxin [12]. Aflatoxin B and G are mainly found in the cake and a minority in the crude oil [7].

The cocoa tree (Theobroma cacao L.), the Malvaceae family is a tropical plant cultivated for its beans which are extracted powder and cocoa butter [13]. Cocoa is an important source of income for small farmers, who are responsible for the bulk of world production [14]. Cocoa production is also a source of foreign currency for producer countries including Côte d'Ivoire. Indeed, the Côte d'Ivoire is the world's largest cocoa producer with about $40 \%$ of world production. This sector accounts for $15 \%$ of gross domestic product and exports of processed cocoa and cocoa beans represent nearly $45 \%$ of export earnings of the country [15], [16]. It employs about 600000 farmers and is the source of income for more than a third of the Ivorian population. Also this sector occupies $40 \%$ of the country's banking sector activities [17]. The importance of this crop for both sectors directly or indirectly bound to it, in fact a lever for economic development and poverty reduction. However, only $35 \%$ of Ivorian cocoa is now processed locally [15].

Ivorian cocoa is exported to Europe and North America as beans, cocoa butter and cocoa powder [18], [19]. The exported products such analysis indicates that the exported proportions are respectively $69.1 \%, 29.9 \%$ and $1.0 \%$ for beans, derivatives and waste [19]. Tagro et al. (2007) identified in the Ivorian cocoa, Aspergillus species such as Apergillus flavu [20]. This species is suspected to produce aflatoxins [1]. However in Côte d'Ivoire the emphasis is on the presence of ochratoxin A in cocoa and derived products to the detriment of aflatoxins [21]-[24]. Furthermore, the presence of aflatoxins in cocoa and derivatives has been reported in Japan [25], in Turkey [26] and Brazil [27], [28].

This study was initiated to determine the level of contamination and estimate the daily intake of aflatoxins from crushed cocoa beans (cocoa mass), produced in Côte d'Ivoire, after roasting and shelling. 


\section{International Journal of Science and Research (IJSR) \\ ISSN (Online): 2319-7064 \\ Index Copernicus Value (2013): 6.14 | Impact Factor (2015): 6.391}

\section{Material and Methods}

\subsection{Sampling}

The plant material used consists of shredded cocoa beans, obtained after roasting and husking (cocoa mass), collected during the 2011-2012 and 2012-2013 crops from processors of cocoa beans. Thus 66 and 47 samples were taken respectively, according to regulation 401/2006 / EC [29], during crops 2011-2012 and 2012-2013.

\subsection{Determination of aflatoxins}

\subsubsection{Extraction method of aflatoxins}

In a $250 \mathrm{~mL}$ Erlenmeyer flask containing $20 \mathrm{~g}$ of cocoa mass, $100 \mathrm{ml}$ of methanol-water $(\mathrm{v} / \mathrm{v}, 8: 2)$ were added. The mixture was homogenized by shaking for 2 minutes and then stored at room temperature in the dark for 12 hours. The homogenate was filtered through filter paper and $50 \mathrm{ml}$ of the filtrate were added $40 \mathrm{ml}$ of zinc sulfate phosphotungstic acid mixture in water (w/w; $50 / 150$ in $1 \mathrm{~L}$ of water) then stored at room temperature for 15 minutes. The mixture was filtered through filter paper and aflatoxins were extracted from the filtrate with 3 volumes of $10 \mathrm{ml}$ of chloroform [30]. The extracts were collected and evaporated to dryness using a rotary evaporator at $40^{\circ} \mathrm{C}$. A dry extract were added 0.4 $\mathrm{mL}$ of hydrochloric acid and $4.6 \mathrm{~mL}$ of bidistilled water. The mixture was filtered using a rezist filter in a chromatographic tube and aflatoxin analysis was made by High Performance Liquid Chromatography (HPLC).

\subsubsection{Equipment}

A liquid chromatograph HPLC brand Shimadzu coupled to a fluorescence detector was used and the operating conditions are described in Table 1.

Table 1: Operating conditions of HPLC analysis

\begin{tabular}{|c|c|c|c|c|}
\hline Pre column & \multirow{2}{*}{\multicolumn{4}{|c|}{$\begin{array}{c}\text { Shim-pack GVP-ODS } 10 \text { x 4,6 mm } \\
\text { Shim-pack GVP-ODS } 250 \mathrm{~mm} \text { x 4,6 mm }\end{array}$}} \\
\hline Column & & & & \\
\hline Detector & \multicolumn{4}{|c|}{$\begin{array}{c}\text { Fluorescence, } \lambda \text { excitation : } 365 \mathrm{~nm}, \lambda \\
\text { emission }: 435 \mathrm{~nm}\end{array}$} \\
\hline Mobile phase & \multicolumn{4}{|c|}{$\begin{array}{c}\text { Water / acetonitrile / methanol (6/2/2, } \\
\mathrm{v} / \mathrm{v} / \mathrm{v})\end{array}$} \\
\hline Injection volume & \multicolumn{4}{|c|}{$20 \mu \mathrm{L}$} \\
\hline Flow rate & \multicolumn{4}{|c|}{$1 \mathrm{~mL} / \mathrm{min}$ gradient } \\
\hline $\begin{array}{l}\text { Temperature of the } \\
\text { Column }\end{array}$ & \multicolumn{4}{|c|}{$40^{\circ} \mathrm{C}$} \\
\hline Rinsing solvent & \multicolumn{4}{|c|}{ Methanol } \\
\hline Duration of analysis & \multicolumn{4}{|c|}{13 minutes } \\
\hline & AFB1 & AFB2 & AFG1 & AFG2 \\
\hline $\begin{array}{l}\text { Limit of Detection } \\
(\mathrm{LD} ; \mathrm{ng} / \mathrm{kg})\end{array}$ & $5 \pm 2$ & $2 \pm 1$ & $3 \pm 1$ & $4 \pm 2$ \\
\hline $\begin{array}{l}\text { Limit of quantitation } \\
\text { (LQ ; ng/kg) }\end{array}$ & $30 \pm 10$ & $40 \pm 20$ & $40 \pm 20$ & $30 \pm 10$ \\
\hline Recovery rate $(\%)$ & $79 \pm 0.9$ & $82 \pm 0.8$ & $85 \pm 0.6$ & $80 \pm 0.8$ \\
\hline
\end{tabular}

\subsection{Estimated daily intake of aflatoxins from mass cocoa}

Deterministic approach was adopted to assess exposure to aflatoxins. This approach consists in multiplying a fixed value of food consumption by a fixed value of the contamination and to divide the consumption by the actual body weight of the individual [31], [32]. The aflatoxin intake was calculated using the formula 1 .

$$
\boldsymbol{A A F}=\frac{(\text { Conc } A F \times Q \text { tep })}{M c}
$$

AAF: daily intake of aflatoxin $\mathrm{Pg} / \mathrm{kg}$ Pc/day for a $70 \mathrm{~kg}$ individual

Conc AF: concentration of aflatoxins in $\mathrm{pg} / \mathrm{kg}$ of product Qtep: amount of product consumed in $\mathrm{kg} / \mathrm{day}$

Mc: body weight in $\mathrm{kg}$

According to the International Cocoa Organization, the daily consumption of cocoa for the Ivorian adult is 1.345 $\mathrm{g} /$ capita/day [33]. On the one hand, estimates intakes were obtained for average and maximum contamination levels and, on the other hand to the maximum tolerated concentrations of $2 \mu \mathrm{g} / \mathrm{kg}$ and $4 \mu \mathrm{g} / \mathrm{kg}$ for AFB1 and AFT respectively [34]. The estimated intakes were compared to the VTR (DJTP equal to $150 \mathrm{pg} / \mathrm{kg} /$ day) established by the European and International Scientific Committees [35]-[38]. The results were expressed as the percentage contribution of the VTR for B1 and total aflatoxins.

\subsection{Statistical analysis}

The averages were calculated with confidence intervals to assess the level of contamination in aflatoxins. The percentages have allowed to assess the occurrence of aflatoxins in mass cocoa samples and the proportions of the estimated intakes of aflatoxins compared to the VTR. The homogeneity of the averages (aflatoxins) was evaluated by analysis of variance with a factor (sampling period), through the F test, from software XLSTAT 7.5 and Excel at risk 5\%.

\section{Results}

\subsection{Measuring the concentrations of aflatoxins}

The average concentration of aflatoxin B1 $(1.31 \mu \mathrm{g} / \mathrm{kg})$ and maximum concentration $(13.87 \mu \mathrm{g} / \mathrm{kg})$ were observed during the campaign 2011/2012. For AFB2, the average concentration is $0.31 \mu \mathrm{g} / \mathrm{kg}$. Regarding the $\mathrm{AFG} 1$ and $\mathrm{AFG} 2$, average concentrations are $0.31 \mu \mathrm{g} / \mathrm{kg}$ and 0.43 $\mu \mathrm{g} / \mathrm{kg}$ respectively. The results show that AFB1, AFB2, $\mathrm{AFG} 1$ and $\mathrm{AFG} 2$ were quantified respectively in $58 \%, 52 \%$, $36 \%$ and $58 \%$ of the 113 samples analyzed (Table 2). 


\section{International Journal of Science and Research (IJSR) \\ ISSN (Online): 2319-7064 \\ Index Copernicus Value (2013): 6.14 | Impact Factor (2015): 6.391}

Table 2: Concentrations and variation field of aflatoxins and proportion of positive samples

\begin{tabular}{|c|c|c|c|c|c|}
\hline & \multicolumn{5}{|c|}{ Concentrations and domain variation $(\mu \mathrm{g} / \mathrm{kg})$} \\
\hline Crops & AFB1 & AFB2 & AFG1 & AFG2 & AFT \\
\hline 2011-2012 & $\begin{array}{c}1.73 \pm 0.69 \\
{[<0.005-} \\
13.87]\end{array}$ & $\begin{array}{c}0.32 \pm 0.12 \\
\mathrm{a} \\
{[<0.002-} \\
2.82]\end{array}$ & $\begin{array}{c}0.29 \pm \\
0.12 \mathrm{a} \\
{[<0.003-} \\
3.18]\end{array}$ & \begin{tabular}{|c|}
$0.64 \pm 0.24$ \\
$\mathrm{a}$ \\
{$[<0.004-$} \\
$7.08]$
\end{tabular} & $\begin{array}{l}2.97 \pm 0.86 a \\
\text { [nd-17.48] }\end{array}$ \\
\hline $2012-2013$ & $\begin{array}{c}1.01 \pm 0.23 c \\
{[<0.005-} \\
5.33]\end{array}$ & $\begin{array}{c}0.31 \pm 0.08 \\
\mathrm{a} \\
{[<0.002-} \\
1.86]\end{array}$ & $\begin{array}{c}0.33 \pm \\
0.12 \mathrm{a} \\
{[<0.003-} \\
3.83]\end{array}$ & $\begin{array}{c}0.28 \pm \\
0.07 \mathrm{c} \\
{[<0.004-} \\
1.96]\end{array}$ & $\begin{array}{c}1.92 \pm \\
0.31 \mathrm{c} \\
\text { [nd- } \\
7.34]\end{array}$ \\
\hline All samples & $\begin{array}{c}1.31 \pm 0.48 \\
b \\
{[<0.005-} \\
13.87]\end{array}$ & \begin{tabular}{|c|}
$0.31 \pm$ \\
$0.10 \mathrm{a}$ \\
{$[<0.002-$} \\
$2.82]$
\end{tabular} & \begin{tabular}{|c|}
$0.31 \pm$ \\
$0.12 \mathrm{a}$ \\
{$[<0.003-$} \\
$3.83]$
\end{tabular} & \begin{tabular}{|c|}
$0.43 \pm$ \\
$0.17 \mathrm{~b}$ \\
{$[<0.004-$} \\
$7.08]$
\end{tabular} & $\begin{array}{c}2.36 \pm \\
0.61 \mathrm{~b} \\
\text { [nd- } \\
17.48]\end{array}$ \\
\hline \multicolumn{6}{|c|}{ Percent positive samples (> LQ) } \\
\hline Crops & AFB1 & AFB2 & AFG1 & & AFG2 \\
\hline $2011-2012$ & 36 & 34 & 28 & & 45 \\
\hline $2012-2013$ & 73 & 65 & 42 & & 68 \\
\hline All samples & 58 & 52 & 36 & & 58 \\
\hline
\end{tabular}

The averages of column followed by the same letter are not significantly different at risk 5\%; nd: not determined

\subsection{Proportion of samples non-compliant with European standards}

Table 3 shows that $20 \%$ of samples have AFB1 concentrations above $2 \mu \mathrm{g} / \mathrm{kg}$. For AFT, $16 \%$ of samples have concentrations greater than $4 \mu \mathrm{g} / \mathrm{kg}$. The maximum permissible limits (LMA) are $2 \mu \mathrm{g} / \mathrm{kg}$ for AFB1 and $4 \mu \mathrm{g} / \mathrm{kg}$ for AFT.

Table 3: Proportion of samples non-compliant with the European standard on aflatoxins

\begin{tabular}{|c|c|c|c|c|c|}
\hline \multicolumn{6}{|c|}{ Percentage non-compliant samples (> $2 \mu \mathrm{g} / \mathrm{kg})^{*}$} \\
\hline Crops & AFB1 & AFB2 & AFG1 & AFG2 & AFT \\
\hline $2011-2012$ & 21 & 6 & 4 & 13 & 36 \\
\hline $2012-2013$ & 20 & 0 & 3 & 0 & 39 \\
\hline All samples & $\mathbf{2 0}$ & 3 & 4 & 5 & 38 \\
\hline \multicolumn{7}{|c|}{ Percentage non-compliant samples $(>4 \mu \mathrm{\mu g} / \mathrm{kg})^{*}$} \\
\hline Crops & AFB1 & AFB2 & AFG1 & AFG2 & AFT \\
\hline $2011-2012$ & 17 & 0 & 0 & 2 & 26 \\
\hline $2012-2013$ & 5 & 0 & 0 & 0 & 9 \\
\hline All samples & 10 & 0 & 0 & 1 & $\mathbf{1 6}$ \\
\hline
\end{tabular}

\subsection{Daily intake of aflatoxin from mass cocoa in an adult Ivorian}

Aflatoxin intakes estimated for an Ivorian average consumer are $25.17 \mathrm{pg} / \mathrm{kg}$ body weight/day and $45.35 \mathrm{pg} / \mathrm{kg}$ body weight/day, respectively for AFB 1 and AFT. While those determined for a large Ivorian consumer are $266.5 \mathrm{pg} / \mathrm{kg}$ body weight/day and $335.8 \mathrm{pg} / \mathrm{kg}$ body weight/day, respectively for AFB1 and AFT. Intakes determined from Authorized Maximum Limits (LMA) are $38.43 \mathrm{pg} / \mathrm{kg}$ body weight/day and $76.86 \mathrm{pg} / \mathrm{kg}$ body weight/day, respectively for AFB1 and AFT. For an average consumer, AFB1 and AFT intakes are lower than those determined from the LMA and VTR established by the Scientific Committees European and international (JECFA and SCF). As against for a large consumer, the determined intakes are much higher than those estimated from the LMA and VTR (Table 4).
Table 4: Daily intake of aflatoxins from cocoa mass in adult Ivorian (Intake in $\mathrm{pg} / \mathrm{kg}$ body weight/day)

\begin{tabular}{|c|c|c|c|}
\hline & AFB1 & AFT \\
\hline \multicolumn{2}{|c|}{ Estimated intake from LMA of AFB1 } & \multicolumn{2}{|c|}{38.43} \\
\hline \multicolumn{2}{|c|}{ Estimated intake from LMA of AFT } & \multicolumn{2}{|c|}{76.86} \\
\hline \multirow{2}{*}{$\begin{array}{l}\text { Estimated intake from } \\
\text { our values }\end{array}$} & Average & 25.17 & 45.35 \\
\hline & Large consumer & 266.5 & 335.8 \\
\hline \multicolumn{2}{|c|}{ Reference value SCF and JECFA } & \multicolumn{2}{|c|}{150} \\
\hline
\end{tabular}

\subsection{Comparison of aflatoxin intakes from mass cocoa with reference values}

For an average consumer, AFB 1 and AFT intakes from mass cocoa represent $65.5 \%$ and $59.0 \%$, respectively of intakes calculated from the LMAB1 and LMAT. Intakes of AFB1 and AFT in cocoa mass represent respectively $16.8 \%$ and $30.2 \%$ of VTR. Regarding the large consumer, intakes of AFB1 and AFT from cocoa mass represent $693.5 \%$ and $437.0 \%$, respectively of the intakes calculated from LMAB 1 and LMAT. Intakes of AFB1 and AFT from cocoa mass represent respectively $177.7 \%$ and $223.9 \%$ of VTR (Table 5).

Table 5: Comparison of aflatoxins intakes from mass cocoa with reference values $(\%)$

\begin{tabular}{|l|c|c|c|c|}
\cline { 2 - 5 } \multicolumn{1}{c|}{} & \multicolumn{2}{c|}{ AFB1 } & \multicolumn{2}{c|}{ AFT } \\
\cline { 2 - 5 } \multicolumn{1}{c|}{} & Average & $\begin{array}{c}\text { Large } \\
\text { consumer }\end{array}$ & Average & $\begin{array}{c}\text { Large } \\
\text { consumer }\end{array}$ \\
\hline AE/LMAB1 & $\mathbf{6 5 . 5}$ & $\mathbf{6 9 3 . 5}$ & 118.0 & 874.0 \\
\hline AE/LMAT & 32.7 & 346.7 & $\mathbf{5 9 . 0}$ & $\mathbf{4 3 7 . 0}$ \\
\hline AE/VTR & $\mathbf{1 6 . 8}$ & $\mathbf{1 7 7 . 7}$ & $\mathbf{3 0 . 2}$ & $\mathbf{2 2 3 . 9}$ \\
\hline
\end{tabular}

AE: estimated intake from the average or maximum;

LMAB1: estimated intake from LMA related to aflatoxin B1;

LMAT: estimated intake from LMA related to total aflatoxins ;

VTR: Toxicological Reference Value; $150 \mathrm{pg} / \mathrm{kg}$ body weight/day.

\section{Discussion}

Aflatoxins B1, B2, G1, and G2 are found in Ivorian cocoa mass. Aflatoxin B1 is quantified in 58\% of samples analyzed. However, it has an average concentration below the Maximum Authorised Limit (LMA) of $2 \mu \mathrm{g} / \mathrm{kg}$ set by European Commission for oilseeds [34]. For against, 20\% of samples have their concentration higher than said standard with maximum concentration of $13.87 \mu \mathrm{g} / \mathrm{kg}$. Turcotte et al. (2013) obtained different results from our and the difference could be explained by the number of samples used by them [39]. Indeed, they determine an average concentration of AFB 1 of $0.86 \mu \mathrm{g} / \mathrm{kg}$ and it was quantified in $93 \%$ of 15 samples which $7 \%$ had concentrations above $2 \mu \mathrm{g} / \mathrm{kg}$. Regarding AFB2, AFG1 and AFG2, the found average concentrations are less than $1 \mu \mathrm{g} / \mathrm{kg}$. The AFT also have an average concentration below the LMA of $4 \mu \mathrm{g} / \mathrm{kg}$ set by the European Commission [34]. However, $16 \%$ of samples have concentrations higher than this standard with maximum concentration of $17.48 \mu \mathrm{g} / \mathrm{kg}$.

The concentrations of AFB1 and AFT determined during the 2012-2013 crop are less than those obtained during the 


\section{International Journal of Science and Research (IJSR) \\ ISSN (Online): 2319-7064 \\ Index Copernicus Value (2013): 6.14 | Impact Factor (2015): 6.391}

2011-2012 crop. This decrease could be explained by the implementation of the reform of the coffee-cocoa sector. According to the Coffee and Cocoa Board, the benefits of advocacy and technical assistance to farmers have contributed to improving the quality of production. Specifically, this resulted in the decrease of the moisture content of cocoa beans from $12 \%$ to $8 \%$ and the rate of foreign material in crops by $3 \%$ to $1.1 \%$ between 2012 and 2013 [15], [40]. According to work by Kouadio et al. (2015) higher the moisture content of cocoa beans is important higher the percentage of contamination (fungus and mycotoxins) increased [41].

For an Ivorian average consumer, intake of AFB1 calculated represents $65.5 \%$ and $16.8 \%$ of the contribution calculated from LMA set by the European Commission [34] and VTR [35]-[38] respectively. Concerning AFT, this intake represents $59.0 \%$ and $30.2 \%$ of the calculated intake from the LMA [34] and the VTR [35]-[38] respectively. High intakes of aflatoxins were calculated from other power supplies. In 1998, the estimated average intake for French population in AFB1 and AFT are respectively $130 \mathrm{pg} / \mathrm{kg}$ body weight/day and $120 \mathrm{pg} / \mathrm{kg}$ body weight/day [42]. These intakes of AFB1 and AFT represent $86.7 \%$ and $80 \%$ of the VTR respectively. Under this standard on VTR, aflatoxin levels detected in the Ivorian cocoa mass are safe for an average consumer [35]-[38]. However, health risks related to the synergy of toxins remain [39], [43]-[46]. In fact, fixing these health standards guarantee an acceptable level of food security. But it is essential to mention the difficulty of estimating the risks of repeated ingestion of aflatoxins in the medium and long-term. The exposure over long periods at very low doses and toxic interactions occurring between mycotoxins and other pathogens may have health consequences of this consumer. As regards a large Ivorian consumer, intake of AFB1 calculated represents $693.5 \%$ and $177.7 \%$ of intake calculated from LMA [34] and VTR [35][38] respectively. As to AFT, this intake represents 437.0\% and $223.9 \%$ of calculated intake from LMA [34] and VTR [35]-[38] respectively. These results indicate that cocoa can be considered a risk food to consumers exceptional. Indeed, SCF (1994) and JECFA (1999) concluded that exposure levels less than $1 \mathrm{ng}$ of aflatoxins $/ \mathrm{kg}$ body weight/day always contribute to risk of liver cancer [35], [37].

\section{CONCLUSION}

This study has clearly showed the presence of AFB1 and AFT in mass cocoa produced in Côte d'Ivoire. This mycotoxin was quantified in over half of samples collected. The results show that the daily intakes estimated of AFB1 and AFT exceed the VTR of aflatoxins in Ivorian regular consumers of cocoa. Thus this study indicates the need for periodic monitoring of the occurrence of aflatoxins in cocoa mass and other dry products (cereals, cocoa beans, green coffee, peanuts and cashews). Hence, because of the carcinogenic, genotoxic without threshold of this mycotoxin, the only realistic approach is to reduce exposure to as low a level as possible following the ALARA (As Low As Reasonnably Achievable).

\section{References}

[1] CD. Kurtzman, BW. Horn, CW. Hesseltine, "Aspergillus nomius, a new aflatoxin producing species related to Aspergillus flavus and Aspergillus tamari", Antonie van Leeuwenhoek, 53: 174-158, 1987.

[2] M. McLean, M. Dutton, "Cellular interactions and metabolism of aflatoxin: and update", Pharmacol Ther, vol.65: p.163-193, 1995.

[3] GD. Kirk, E. Bah, R. Montesano, "Molecular epidemiology of human liver cancer: insights into etiology, pathogenesis and prevention from the Gambia”, Carcinogenesis 27: 2070-2082, 2006.

[4] CP. Wild, Y. Gong, "Mycotoxins and human disease: A largely ignored global health issue", Carcinogenesis 31 (1): 71-82, 2010.

[5] Y. Liu, F. Wu, "Global Burden of Aflatoxin-induced hepatocellular carcinoma: A Risk Assessment", Environ Health Perspect 118 (6): 818-824, 2010.

[6] J. Keenan, P. Jolly, P. Preko, J. Baidoo, J. Wang, TD. Phillips, JH. Williams, G. McGwin, "Association Between Aflatoxin B1 Albumin Adduct levels and tuberculosis infection Among HIV+ Ghanaians", iMedPub Journals Vol. 2 No. 3:3 doi: 10:3823/230, 2011.

[7] AFSSA (Agence Française de Sécurité Sanitaire des Aliments), "Evaluation des risques liés à la présence de mycotoxines dans les chaînes alimentaires humaine et animale. Rapport synthétique", p 82, décembre 2006.

[8] JL. Richard, "Mycotoxins, Toxicity and Metabolism in Animals- A system Approach Overview. Mycotoxins and Phycotoxins-Developpements in Chemistry", Toxicology and Food Safety, Ed by M. Miraglia H., van Egmond C., Brera and J. Gilbert. USA: 363- 397, 1998.

[9] YY. Gong, V. Egal, A. Hounsa, PC. Turner, AJ. Hall, V. Cardwell, CP. Wild, "Determinants of aflatoxin exposure in young children from Benin and Togo, West Africa: the critical role of weaning", Int. J. Epidemiol. 32: 556-562, 2003.

[10] YY. Gong, A. Hounsa, El. Sharif, PC. Turner, AE. Sutcliffe, AJ. Hall, K. Cardwell, CP.Wild, "Post weaning exposure to aflatoxin results in impaired child growth: A longitudinal study in Benin, West Africa", Environ. Health Perspect, pp. 112-113, 2004.

[11] Codex Alimentarius, "Programme mixte FAO/WHO sur les normes alimentaires; Comite du Codex sur les contaminants dans les aliments. Avant-projet de niveaux maximaux pour les aflatoxines totales dans les figues sèches (N11-2010)", La Haye, Pays-Bas,CX/CF 11/5/7, 27p, Décembre 2010.

[12] ProMED, "Aflatoxicosis, Human-Kenya", 2004 [Online] Available: www.promed.isid.harvard.edu [Accessed: May 09, 2006].

[13] WS. Alverson, BA. Whitlock, R. Nyffeler, C. Bayer, DA. Baum, "Phylogeny of the core Malvales: evidence from ndhF sequence data", American Journal of Botany, 86: 1474-1486, 1999.

[14] KE. Adabe, EL. N'Go-Samnick, "Production et transformation du cacao", La collection Pro-Agro ; CTA et ISF, p44, 2014.

[15] CCC (Conseil du Café-Cacao), "Contrôle qualité-prix du café et cacao", Direction des opérations techniques, 10p, mars 2014. 


\section{International Journal of Science and Research (IJSR) \\ ISSN (Online): 2319-7064 \\ Index Copernicus Value (2013): 6.14 | Impact Factor (2015): 6.391}

[16]FAO, "Production: Cultures", Retrieved Février 20, 2014 [Online]

http://faostat3.fao.org/faostat-

gateway/go/to/download/Q/QC/F [Accessed: January 13, 2015].

[17] Y. Keho, SS. Diallo, JL. Agkpo, "Modélisation de la production cacaoyère en Côte d'Ivoire", IITA/STCP, 2008.

[18] ICCO, "Production of Cocoa Beans. Quarterly Bulletin of Cocoa Statistics", posted 22 October 2007 [online]. Available:

http://www.icco.org/statistics/production.aspx.

[Accessed: February 20, 2008].

[19] BCC, “Analyse de la commercialisation du café et du cacao, campagne 2006-2007". Rapport technique du 1 octobre 2006 au 30 septembre 2007. p 6, Version finale du 30 janvier 2008.

[20] SG. Tagro, D. Michael, C. Emile, F. Gérard, R. Robert, M. Guy, CV. Anne, "Identification and Lipaseproducing Abilities of Moulds Isolated from Ivorian Raw Cocoa Beans", Research Journal of Agriculture and Biological Sciences, 3 (6): 838-843, 2007.

[21] A. Dembele, A. Coulibaly, K. Traore, M. Kone, N. Silue, G. Fourny, AA. TOURE, "Détermination du niveau de contamination par l'ochratoxine A (OTA) du cacao à l'exportation", TROPICULTURA, 27, 1, pp 2630, 2009.

[22] A. Coulibaly, A. Dembele, GHM. BIEGO, N. Silue, A. Toure, "Evolution of the Merchantability and the Level of Ochratoxin A of Ivorian Cocoa Beans from Production Areas during the Harvest Season", Sustainable Agriculture Research; Vol. 1, No. 2; 2012.

[23] A. Coulibaly, A. Dembele, GHM. BIEGO, KM. Bohoussou, A. Toure, "Determination of ochratoxin A levels in ivorian cocoa beans intended for exportation", Int. J. Biol. Chem. Sci. 6 (5): 1910-1916, October 2012.

[24] A. Coulibaly, GHM. BIEGO, A. Dembele, KM. Bohoussou, A. Toure, "Cocoa Beans and Cocoa Derivatives from Cote-D'Ivoire: Investigating Ochratoxin A Level and Assessing Dietary Intake Adults", Sustainable Agriculture Research, Vol. 2, No. 1; 173-180, 2013.

[25] Y. Sugita-Konishi, T. Sato, S. Saito, M. Nakajima, S. Tabata, T. Tanaka, H. Norizuki, Y. Itoh, S. Kai, K. Sugiyama, Y. Kamata, N. Yoshiike, S. Kumagai, "Exposure to aflatoxins in Japan : risk assessment for aflatoxin B1", Food Addit Contam A 27:365-372, 2010.

[26] P. Ulca, MK. Evcimen, HZ. Senyuva, "Surveys of aflatoxin B1 contamination of retail Turkish foods and of products intended for export between 2007 and 2009”, Food Addit Contam B 3:120-125, 2010.

[27] MV. Copetti, BT. Iamanaka, JL. Pereira, MH. Fungaro, MH. Taniwaki, "Aflatoxigenic fungi and aflatoxin in cocoa", Int J Food Microbiol 148:41-44, 2011.

[28] MV. Copetti, BT. Iamanaka, JL. Pereira, DP. Lemes, F. Nakano, MH. Taniwaki, "Determination of aflatoxins in by-products of industrial processing of cocoa beans", Food Addit Contam A 29:972-978, 2012.

[29] Commission Européennes, "Règlement (CE) No 401/2006 de la commission du 23 février 2006 portant fixation des modes de prélèvement d'échantillons et des méthodes d'analyse pour le contrôle officiel des teneurs en mycotoxines des denrées alimentaires", Journal Officiel de l'Union Européenne L70/12, 2006.

[30]B. Le Tutour, A. Tantaoui-Elaraki, A. Bullerman, "Recherche de l'aflatoxine B1, de l'ochratoxine A et de la zéaralénone dans les farines de blé", Actes Inst. Agron. Vét. (Maroc) 3: 65-69, 1983.

[31]R. Kroes, D. Muller, J. Lambe, P. Verger, A. Visconti, "Assessment of intake from the diet" Food and Chemical Toxicology, vol.40, p.327-385, 2002.

[32] OMS (Organisation Mondiale de la Santé), "Régime alimentaire, nutrition et prévention des maladies chroniques", Rapport d'une consultation OMS/FAO d'experts, Genève, OMS, Série de rapport technique, $\mathrm{n}^{\circ}$ 916, p189, 2003.

[33] ICCO, "Assessment of the movement of global supply and demand", p32, 2006.

[34] UE (Union Européenne), “Règlement (UE) N¹65/2010 de la commission du 26 février 2010 modifiant le règlement $(\mathrm{CE}) \mathrm{N}^{\circ}$ 1881/2006 portant fixation de teneurs maximales pour certains contaminants dans les denrées alimentaires, en ce qui concerne les aflatoxines", L50/8, p5, 2010.

[35] SCF (Scientific Committee for Food), "European Commission DG XXIV Unit B3. Thirty-fifth report. Opinion on Aflatoxins B1, B2, G1 et G2 and M1", Expressed on 23 September, 1994.

[36]CSHPF (Conseil Supérieur d'Hygiène Publique de France), "Les mycotoxines dans l'alimentation : évaluation et gestion du risque", éds TEC \& DOC, 1999.

[37] JECFA (Joint FAO/WHO Expert Committee on Food Additives and Contaminants), "Evaluation of certain food additives and contaminants", Fourty-nine report, WHO Technical Report Series N. 884, p69-77, Geneva, 1999.

[38] JECFA, (Joint FAO/WHO Expert Committee on Food Additives and Contaminants), "Safety evaluation of certain mycotoxins in food", WHO Food Additif Series; 47, 2001.

[39] AM. Turcotte, PM. Scott, B. Tague, "Analysis of cocoa products for ochratoxin A and aflatoxins", Mycotoxin Res, 29:193-201, 2013.

[40] DER (Direction des Etudes et de la Recherche), "Etude monographique sur la filière cacao dans l'UEMOA", Imprimerie BCEAO, p33, juin 2014

[41] Kouadio AKA., S. AW, NE. Assidjo, LP. Kouame, "Study of physicochemical and mycologic quality of Theobroma Cocoa product in Yamoussoukro and Soubré (Côte d'Ivoire)", International Journal of Innovation and Scientific Research Vol. 13 No. 1 Jan. 2015, pp. 330-340, 2015.

[42] PH. Verger, JL. Volatier, A. Dufour, "Estimation des niveaux théoriques d'ingestion d'aflatoxines et d'ochratoxine. Dans: Les mycotoxines dans l'alimentation: évaluation et gestion du risque", édsTEC \& DOC, Lavoisier, 1999.

[43] CM. Placinta, JPF. D'Mello, AMC. Macdonald, "A review of worldwide contamination of cereal grains and animal feed with Fusarium mycotoxins", Animal Feed Science and Technology, 78: 21-37, 1999.

[44] S. Kumagai, M. Nakajima, S. Tabata, E. Ishikuro, T. Tanaka, H. Norizuki, Y. Itoh, K. Aoyama, K. Fujita, S. Kai, T. Sato, S. Saito, N. Yoshiike, Y. Sugita-Konishi, 


\section{International Journal of Science and Research (IJSR) \\ ISSN (Online): 2319-7064}

Index Copernicus Value (2013): 6.14 | Impact Factor (2015): 6.391

"Aflatoxin and ochratoxin A contamination of retail foods and intake of these mycotoxins in Japan", Food Addit Contam A 25:1101-1106, 2008.

[45] S. Tabata, K. Iida, K. Kimura, Y. Iwasaki, M. Nakazato, K. Kamata, M. Hirokado, "Investigation of ochratoxin $\mathrm{A}, \mathrm{B}$ and citrinin contamination in various commercial foods [in Japanese]", Shokuhin Eiseigaku Zasshi 49:111-115, 2008.

[46] MV. Copetti, BT. Iamanaka, JL. Pereira, DP. Lemes, F. Nakano, MH. Taniwaki, "Co-occurrence of ochratoxin A and aflatoxins in chocolate marketed in Brazil" Food Control 26:36-41, 2012.

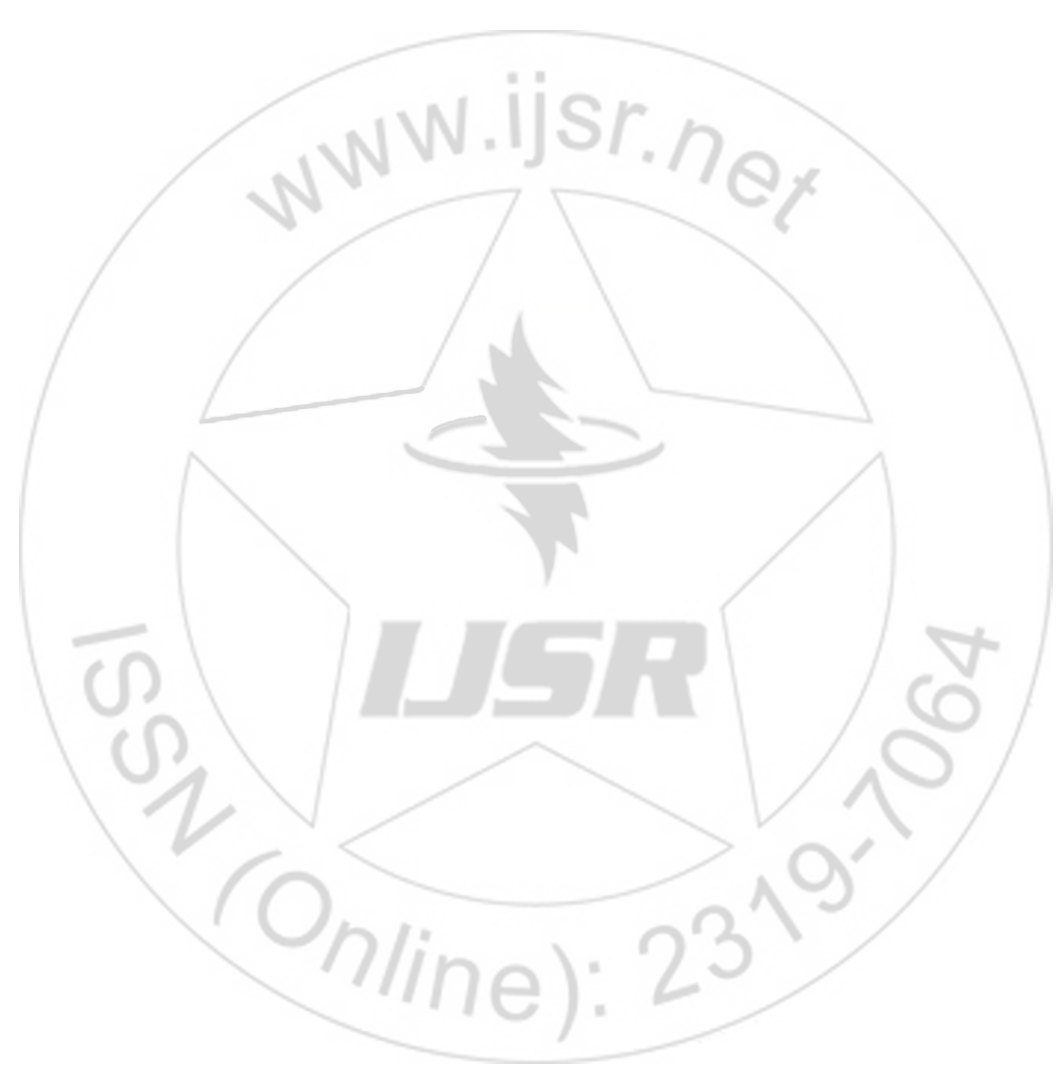

Volume 5 Issue 5, May 2016 www.ijsr.net 